(e-migrinter

e-Migrinter

$5 \mid 2010$

Migrations dans les pays nordiques

\title{
New explorations in Finnish migration studies: the emerging case of the skilled migrants
}

\section{Kaisu Koskela}

\section{(2) OpenEdition \\ Journals}

\section{Electronic version}

URL: https://journals.openedition.org/e-migrinter/2082

DOI: 10.4000/e-migrinter.2082

ISSN: 1961-9685

Publisher

UMR 7301 - Migrinter

\section{Printed version}

Date of publication: 28 April 2010

Number of pages: $57-67$

ISSN: 1961-9685

\section{Electronic reference}

Kaisu Koskela, "New explorations in Finnish migration studies: the emerging case of the skilled migrants", e-Migrinter [Online], 5 | 2010, Online since 20 April 2020, connection on 20 May 2021. URL: http://journals.openedition.org/e-migrinter/2082 ; DOI: https://doi.org/10.4000/e-migrinter.2082 


\section{New explorations in Finnish migration studies: the emerging case of the skilled migrants}

Kaisu Koskela

$\mathbf{F}$ inland has traditionally not been a country of immigration. The number of immigrants is still comparatively small. Research in the field has concentratedon culturally distant groups and their problems in integrating into Finnish society. The first studies of $2^{\text {nd }}$ generation immigrants have recently also added to the academic discussion.

However, a new field within Finnish migration studies is now emerging, that of the study of the highly-skilled migrant labour force. This is still a very small group within the immigration statistics, but one that differs vastly from the immigration that Finland has previously received. The skilled migrants are generally seen as an economic concern, and much of the research reflects this.

Therefore issues related to the social sphere and integration have been to a large extent ignored. This article will look at the initial results of this emerging research field, and offer recommendations for future research while drawing links between relevant research and policy making.
Introduction

Immigration is a relatively new phenomenon in Finland. The first noticeable groups of immigrants arrived in the early 1990's from Somalia as refugees. Before that there had only been very small numbers of refugees coming from Chile and Vietnam in the late 1970's (Forsander, 2002). Migration in larger numbers started even later when the government passed a law allowing so called ethnic return migration ${ }^{1}$ of people of Finnish descent from the territory of Ingria in today's Russia. An estimated $25000-30$ 000 Ingrian Finns ${ }^{2}$ have arrived to Finland since 1990. Finnish immigration is also characterised by an un-proportionate number of marriage-migrants ${ }^{3}$ and family reunifications.

All in all, immigration is characterised largely by humanitarian reasons. Immigration from other EU nations is still small, but has slowly picked up since Finland joined EU in 1995. At the end of 2008 there were 143256 people of foreign nationalities living in Finland (Statistics Finland, 2008). The largest groups come from Russia, Estonia, Sweden and Somalia. The overall number of immigrants is very small compared to other European countries, making up only $2.7 \%$ of the whole population of Finland compared to for example $12.3 \%$ in Sweden (UN Department

\footnotetext{
1 The law is based on the kindred peoples thinking; 'return' migration is allowed for those that are able to prove that at least two out of four grandparents are ethnic Finns.

2 Estimates vary largely because return migration in its early stages was largely uncontrolled. In addition, Ingrians get lost in statistics as Russian nationals.

3 I.e. people migrating to Finland because of a Finnish spouse. Foreign wives most often come from Russia, Estonia and Thailand, and husbands from UK, US, and Turkey (Janinskaja-Lahti et al, 2002).
} 
of Economic and Social Affairs' Population Division, 2007).

All of the existing immigrant groups can be described as non-labour force migrants. In fact, labour or economic migration has not been an issue in Finland until very recently. The 'baby boom' generation of post-war Finland, together with an economy in its baby steps, meant that there was little need for the imported labour force necessary for most of Western Europe to work in labour-intensive industries. In fact, while Finland's neighbours sought labour migrants from Southern Europe and elsewhere in the Mediterranean, Finns themselves emigrated in masses in search of better opportunities. During the late 1960's and early 1970's one tenth of the baby boomers emigrated, mainly to Sweden, but in large numbers also to North-America and Australia. Today 1 million people of Finnish descent still live outside of Finland (Sagne et al, 2005). Immigration into Finland started to exceed emigration only at the turn of 1980's to 1990's (Forsander, 2002).

The early 1990's also saw Finland starting to heavily invest in the development of internet and communication technologies. The continued development of this sector has made Finland's economy competitive in the global scale. However, the aging of the native population poses a problem that is expected to be an even bigger economic concern in Finland than in most other Western European nations. By 2015, it is estimated that there will be an equal number of those working to those being dependents in Finland (Forsander, 2002). In 2000, a controversial study estimated that even as many as 2,1 million foreign employees (both skilled and unskilled) are needed by the year 2020 if the current levels of welfare state and its support ration are to be maintained (Wallenius, 2001:12). At present, Finland is not attracting anywhere near such numbers. Furthermore, even fewer of those arriving are considered highly skilled. In comparison to other EU countries, Finland rates very poorly in attracting managerial and professional staff from abroad. Despite the success of the ICT industry, Finland attracts roughly the same amount of skilled workforce as countries such as Greece and Portugal $^{4}$ (Forsander and Raunio, 2005).

To make matters worse, Finland is one of the very few OECD countries that are actually suffering from brain drain ${ }^{5}$, as its own highly educated people are leaving the country for employment opportunities elsewhere at the same time that it has failed to establish itself as a desirable location for skilled migrants coming in (Dumont and Lemaittre, 2005). This situation poses a double threat for a country expecting the same labour shortage in the coming years that its western neighbours have been preparing for a while already ${ }^{6}$. The Finnish government has been criticised for being late to react to the need to attract skilled immigrants. As Forsander puts it: Finland's immigration policy has not been determined by labor market considerations; instead it has developed as a result of external pressures, such as international agreements, or on the basis of ethnic loyalty (2003:56). Recruitment of skilled labour from abroad is still low compared to other EU-countries (ibid, 2004) and policies designed to attract skilled migrants are few. At present, employment permit procedures

\footnotetext{
4 The share of non-nationals in managerial level employment in Finland is 1,3\%, while the EU average is $4,1 \%$. For comparison, the same figure in Sweden is 4,3\% (Forsander and Raunio, 2005:29. Figures based on Auriol and Sexton, 2002).

5 More educated Finns leave Finland than educated immigrants move to Finland. Finland together with Ireland are therefore the only EU-15 countries that are not beneficiaries of worldwide skilled migration flows.

${ }^{6}$ Many countries have adapted their labour migration policies to facilitate the entry of skilled migrants and to allow foreign students to access their labour markets after graduation. Some have also launched specific recruitment programmes. In addition, tax deductions are commonplace (e.g. skilled migrants in Sweden pay no taxes from the first $25 \%$ of their income for the first 10 years, and Norway grants a standard $15 \%$ deduction for a period of 4 years)
} (Dumont and Lemaître, 2005:25). 
are restrictive and slow, and only a few tax deductions are offered for foreigners working in Finland ${ }^{7}$.

The situation is one that needs conscious efforts. Policies that attract and motivate skilled migrants to Finland, and most importantly commit them to stay here, are needed. These policies should be grounded in relevant research that is casespecific to Finland. The right type of research into skilled migration is therefore crucial for Finland not to be left out of the skilled migrant flows so very important in today's global economy.

\section{Research in the field}

Research in the field of skilled migration to Finland is in its baby steps. Studies in the migration field so far have concentrated on longer established, culturally distant groups and their problems with integrating in Finland. Recently the field has also witnessed the first studies of $2^{\text {nd }}$ generation immigrants, an issue that has only become a reality in the past decade. Skilled migrants first started to appear in Finnish academic research in the early 2000's, mainly in discussion of the internationalisation of the labour market and its implications for the economy. The establishment of the European Chemicals Agency (ECHA) in Helsinki in 2007 seems to have spurred a new wave of interest in the subject. There are several interesting ongoing research projects, such as 'InterProF' ${ }^{8}$ that tracks the integration of ECHA workers as a longitudinal study from a social psychology perspective. 'ACRE' in

\footnotetext{
${ }^{7}$ A foreigner working in Finland may qualify for a special tax at a flat rate of $35 \%$ during a period of 24 months if he receives any Finnish-source income for duties requiring special expertise and earns a cash salary of $€ 5,800$ or more per month. This law provides that the expert has not been resident in Finland any time during the five preceding years. (Dumont and Lemaitre, 2005:25).

8 InterProF: Factors Ensuring Integration Among International High Skilled Professionals in Finland. For English summary of the project see Yijälä, 2008.

9 ACRE: Accommodating Creative Knowledge -
}

its turn is in the field of social geography. This international project examines the strengths and weaknesses of the Helsinki metropolitan region as a living environment for highly skilled workforce. My own ethnographic research deals with issues of alterity, social identity and integration among skilled migrants in the Helsinki region ${ }^{10}$. All these studies will no doubt add to our understanding of the specificities of skilled migration to Finland. Furthermore, they will offer insights to the social reality and social integration of these migrants, an issue that has largely been ignored and one that I will concentrate on in this article.

\section{Considerations for terminology}

A few words should be said about terminology. There are many terms used to define what are here referred to as 'skilled migrants'. Expatriates is a term that is often used especially in non-academic writing and also by skilled migrants themselves. However, expatriation in relation to global employment entails an expatriate contract from outside the host country (as opposed to local employment agreement) and therefore implies a predetermined, limited stay. Furthermore, expatriate contracts often retain the person also in the country of the company, making them only partial immigrants, at least at legislative level. In this way expatriates are often what Appleyard has termed professional transient, migrants whose careers keep them in constant transition from place to place (Appleyard, 1989).

A relatively new term in the field is internationals. This term is not related to employment, rather describes the character of the type of people in question; they have lived their lives in various countries, and identify with a global cosmopolitan culture.

Competitiveness of European Metropolitan Regions within the Enlarged Union. See project web-site: http://acre.socsci.uva.nl/

10 Ongoing $\mathrm{PhD}$ research conducted at the Department of Sociology at University of Helsinki 
They are global nomads, free spirits who supposedly go wherever they please, as opposed to nomads of global economy (Trux, 2002:181) who follow employment opportunities. In this sense the term also juxtaposes them against the 'typical' immigrant, which in laymen's terms implies a longer stay often not of one's own choice (i.e. humanitarian immigrants).

'Skilled migrants' is not without its problems either. First of all, measuring who is 'skilled' is difficult. Levels of education have often been used as measurement, but they are seldom included in national statistics on immigration. Furthermore, appreciation for certain skills is dependent on need. Is a construction worker or a nurse then any less skilled than a biotechnology expert or an IT engineer? The final report of the Global Commission for International Migration even suggests that: the traditional distinction between skilled and unskilled workers is in certain respects an unhelpful one [...] While they may have different levels of educational achievement, all of them could be legitimately described as essential workers (2005:7).

Calculating skilled migrants from statistical data is made difficult because of their 'invisibility'. Skilled migrants cannot be identified by gender, age, nationality, language or religion. They also cannot be defined by educational status, visa type or employment status alone. Many are not even registered resident in the country where they work because of employment contracts that keep them in two or more countries. In addition, those who arrive to a country as immigrants but later acquire citizenship get lost in the statistics. The most comprehensive attempt so far to shed light on these issues and to combine national statistics is a 2005 OECD working paper (Dumont and Lemaitre, 2005).

Still, actual numbers are hard to provide. Immigration to Finland for work reasons is estimated to account for around $10 \%$ of the total immigration flow
(Forsander et al, 2008). For the purposes of this article, skilled migrants should be viewed as an umbrella term; many of them may be (or may have been originally) expatriates, most are certainly international (if not internationals), all are immigrants, and some might even identify themselves as 'transient' and 'global'.

\section{Case studies}

Whereas previous migrants arrived into Finland mainly due to humanitarian reasons and were therefore seen as a moral issue, skilled migrants are primarily seen as an economical concern. Much of research has followed this logic. Studies have concentrated largely on the legislative and economic issues of skilled migration (e.g. Kananen, 2006; Forsander, 2002), or on finding out how employers can better attract foreign workforce (e.g. Trux 2000; Sippola et al, 2006). Little is known about the social aspects and the actual experience of living in Finland as a skilled migrant. As is argued, this type of research is paramount for attracting and later committing skilled migrants to Finland.

The following is therefore an overview of case studies that have taken into consideration also life outside the workplace. Reading between the lines of these studies shows that Finland's supposed trump cards of high quality of living standards, safety and nature are not strong enough pull-factors for attracting, and certainly not for committing, skilled migrants to Finland. Furthermore, they imply that the social sphere is where most problems are felt and that it is considered very important when deciding weather to stay on in Finland or not.

\section{Finland in the 'global field of choices': the pull factors}

One of the only long-term researchers of skilled labour migrants in Finland is Mika Raunio. Although much of Raunio's research is also from the point of view of 
economic considerations for companies hiring skilled migrants (e.g. Raunio, 2001; 2005), some is from the perspective of the skilled migrants themselves, on their motivations and choices (Raunio, 2002a; 2002b; 2003). His research gives some insight into the motivations of skilled migrants coming to Finland.

Because of the globalization of economy, skilled migrants move and work in a 'global field of choices' that consists of interconnected nodes or places (rather than states and cities per se). Finland does not fare well in this field. It is often considered distant, expensive, unfamiliar and cold. In addition, Finnish migration and labour policies and their late awakening to the competition for global talent create a major problem; Finland is very little known even as a viable option for skilled migrants. Raunio notes that an actual absence of knowledge creates doubts about the chances of a country to offer meaningful career opportunities or even a decent quality living environment (Raunio and Sotarauta, 2005). In this way Finland's little known reputation may place it outside the 'global field of choices' all together.

Actors in this field of choices can be said to follow three types of reasoning: there are 'global nomads' following economic opportunities, 'quality-of-life migrants' and those migrating for social relationships (like marriage and family) (2002b:6, see also Forsander et al [2004:121] for similar division). In a number of cases the reasons for coming to Finland were related to social relations. However, Raunio finds the majority of his informants to follow the 'global nomads'-logic, motivated by career advancement and financial gain. Other studies (e.g. Hautala, 2006) contradict this and name 'quality-of-life' migration as the main motivation among skilled migrants coming to Finland.

Raunio and Sotarauta's later research (2005) shows that Finland is rarely chosen because of itself. Rather it is chosen because of the job that has been acquired prior to coming to Finland. Similarly, Trux (2002) has found that people choose to work here not because of Finland or because of particular company per se, rather because of the combination of both of them as a package, and in careful comparisons to other (often global) options. Also, again, a central role in this package is played by existing social relations in Finland.

\section{The good and the bad: committing and distancing factors}

Those that do choose Finland, report to appreciating it because of the low-stress character of working conditions and flexibility of the workplace. This relates to long holidays, short working days, and consideration for family responsibilities (Raunio, 2003). Finnish working culture is also considered a 'humane alternative to Silicon Valley' for the possibilities it offers to combine work and family life (Forsander and Trux, 2002:230). Other positive points have been named as equality, safety and the generally slow pace of life (Forsander and Raunio, 2005), as well as nature and cleanliness (Raunio, 2003).

Finnish modes of interaction, associated with poor communication skills and limited conversation, were seen as distancing factors. This also relates to an often reported difficulty in forming social relationships, both with Finns as well as other foreigners. Raunio's research shows that forming friendships and acquiring acquaintances is felt to be especially difficult in Finland because of the small sizes of foreign nationality-clusters. There are also marked differences in social interaction between the immigrants' own culture and Finnish culture, and the Finns are felt to be unfamiliar with foreigners and multiculturalism in general (2002b).

Trux (2002) also reports disappointment in the language skills of 
officials in public services, and a lack of forms and available information in English. In addition, culture and climate are often reported as reasons to leave. Some of Trux's interviewees said they had difficulty in tolerating both 'the cold climate and cold people' (ibid:208)). The remoteness of the country is felt both geographically as well as culturally, and this feeling is magnified by Finland's small size (although this can also be a positive factor for some).

However, the most strongly felt negative factors for skilled migrants living in Finland are connected to the level of salaries and taxation, and to poor opportunities for career advancement. Majority of those interviewed by Raunio did not think it likely that they would seek further employment in Finland after their contracts run out. Their chances of getting a local contract were seen as slim because of lack of social networks and the (often unnecessary) requirement for Finnish language skills (Raunio, 2003). However, those whose (often Finnish) spouse's work was tied to Finland were more willing and likely to try finding further employment in Finland ${ }^{11}$. In fact, it seems that those with any type of social contacts were not only more likely to come to Finland, but are also more likely to stay in the long term.

As for the dissatisfaction in salaries and taxation, only six percent of respondents in Raunio's research 'strongly agree' that their salary is satisfactory and only three percent that their level of taxation is tolerable (ibid:37). Furthermore, the Finnish welfare state, the supposed trump card attracting immigrants, was not seen as a positive, rather a negative factor. Trux has dealt with this in her research (2002). She has concluded that the Finnish welfare state model, upheld by heavy taxation, is simply

\footnotetext{
11 Over $70 \%$ of those planning to remain permanently in Finland had a Finnish spouse or partner. The committing effect is emphasized if the couple bave children of school age or if the spouse's professional skill was linked to Finnish society (e.g. teacher) (Raunio and Sotarauta, 2005:25)
}

not compatible with skilled migrants' wants and needs; its pension schemes, free education and health care are not relevant to most skilled migrants. For many, children's schooling is not even an issue (many are single, and/or have no children), and as far as health care was concerned, it is often provided by the company itself through the private sector, making free public health care useless. Where the public health care was used, its quality (waiting times, payments per visit) was not found satisfactory. Furthermore, as most of those interviewed were not planning to stay in Finland, they were not trusting that they would ever get return for the payments they made every month. All in all, the general feeling is that the skilled migrants are paying to a system that they neither want, nor use themselves. In short, they felt they were paying for the Finnish people's health care and schooling.

\section{Economic versus social factors}

It therefore seems that the logic of skilled migrants themselves also works according to economic considerations, and would thus justify the bias in research. At closer look, however, social factors come to play a larger part than their proportional presentation in statistics might lead one to believe; although decisions to come to Finland are often made according to economic and career related considerations, the decision to stay is largely influenced by social factors. For example: those planning to leave felt less frequently that their place of residence was open and the people easily approachable than those planning to stay (Raunio and Sotarauta, 2005:23) and Failure of adjustment of the spouse is among the biggest reasons for the departure of a foreign employee from the company (Trux, 2002:204).

Although one of the biggest complaints from skilled migrants in Finland is connected to levels of wages and taxation, these are not sufficient factors to push them out of the country. Rather that decision rests in the social sphere. Raunio and Sotarauta 
agree: Being an outsider both in one's own work community and in society is formed from many factors, but from the perspective of the individual it is clearly a factor which disconnects or even pushes from the region. High quality of living environment or safety will not be sufficient to keep skilled migrants in Finland if other factors are not right (2005:23).

\section{Living environment}

Lastly, the importance of living environment is another factor that has started to attract attention. Kepsu and Vaattovaara's (2008) report for the ACRE project states that 'soft' location factors, which include cultural and leisure amenities, people's attitudes, as well as availability of open green spaces, should be paid more attention to (as opposed to only the 'hard' location factors of salary, transportation and public services). Kepsu and Vaattovaara follow economic geographer Richard Florida's claim that companies will follow where the right workers are available (Florida 2002; Florida and Tinagli, 2004). This would imply that employees do not solely migrate where the work is, rather the work will be available where they are already willing to migrate to. Therefore, for development of urban policies attention should be paid to the movement patterns of people rather than firms, as their consequential relationship may be opposite to that assumed. Kepsu and Vaattovaara interviewed national migrants moving within Finland working in the creative and knowledge intensive industries. In these interviews, soft factors consistently ranked among top four important factors when considering where to live. Especially diversity of leisure and entertainment opportunities was seen as important.

Raunio's research shows that among the skilled migrants in Finland many of these soft factors received low satisfaction ratings. Around half of the respondents felt that their home region did not offer enough cultural activities and night life, and that people were not open and approachable ${ }^{12}$. However, the importance of cultural services and night life were most often not considered as 'very important' nor even 'quite important' factors in the choice of place to live (Raunio and Sotarauta, 2005:20). Therefore, contrary to Kepsu and Vaattovaara's hypothesis, it could be assumed that most of the skilled migrants who do decide to come to Finland are not too concerned about soft location factors in any case. Perhaps those who want a big global city with active cultural and night lives leave Finland out of their field of choices altogether. Kepsu and Vaattovaara's ACRE study is continuing with results from interviews with transnational workers (i.e. skilled migrants). Hopefully it will offer more data for future discussion ${ }^{13}$.

\section{Linking research to policy}

The reviewed studies show that Finland is largely seen as a transitional place. Skilled migrants move here because of interesting and challenging work opportunities that will further their careers, and are therefore willing to put up with low wages and high taxes. However, lack of social contacts (needed both for career advancement and social life), limited or no knowledge of language, difficulty in understanding Finnish modes of communication, and lack of cultural and social activities are all reasons that push skilled migrants to leave Finland. Many see no factors other than their work that would commit them to stay. All in all, it seems that

\footnotetext{
12 The cultural activities of my home region are sufficient (58.2\% 'strongly' or 'mostly agree'); Night life in my home region is lively enough (55\%)(Raunio and Sotarauta, 2005:19, figure 5); The atmosphere of my current home region is open and people approachable (49.2\%); I have enough friends or/and a well functioning social network in my current home region $(61.5 \%)$; The atmosphere of my current home region is international (53\%) (ibid:22, figure 6).

13 Note: since the writing of this article the results of Kepsu and Vaattovaara's interviews with transnational migrants in Helsinki have been published (see References: Kepsu et al, 2009).
} 
skilled migrants are poorly integrated into the Finnish society.

\section{Towards social integration: the role of the third sector}

A recent report (Carroll et al, 2009) commissioned by the City of Helsinki Urban Facts centre recognises three stages in successfully attracting and committing skilled migrants to Finland. First stage is to find and recruit the right type of migrants. Secondly, the company must educate and integrate the skills of these migrants in order to get the best benefits from their 'investment'. The third stage should be to integrate the migrant as an individual, as this is the only way to gain long term benefit by committing the person to stay. This last point is often ignored or poorly executed. Therefore integration stops within the work place, leaving the migrant disconnected from Finland and its society.

Having a life outside the workplace is naturally important for quality of life. The studies previewed show that various levels of social integration, finding meaningful activities and having friends are recognised as important factors for skilled migrants who consider remaining in the country. At the very least, unhappiness in one's social life can bring added pressure to leave. These issues are not, however, part of the official integration programme designed by the state, or even part of the private relocation services often provided by employers ${ }^{14}$.

Issues with social life are therefore left for the individuals themselves to figure out. Help in this matter could be provided by the third sector. The Advisory Board for Ethnic Relations (ETNO), a working group appointed by the Ministry of the Interior, has recommended that the role of the third sector should be clarified and emphasised in

\footnotetext{
14 These relocation services concentrate only on the practicalities after arriving in Finland, such as finding an apartment, getting permits, schooling and healthcare, and finding employment for spouses.
}

the integration of immigrants, and made into an official part of the integration programme. So far the role of third sector organisations has been to work against racism and to maintain cultural contact within any one ethnic/cultural group. Third sector organisations and projects could, however, be very helpful in working as avenues of cross-cultural understanding, as well as integrating and committing also skilled immigrants (ETNO, 2008).

Carroll et al's report agrees. They conclude that the involvement of third sector services geared at establishing social contacts and activities is needed for successful social integration of skilled migrants $(2009)^{15}$. These services can improve knowledge of cultural and communicational differences on both sides and are therefore ultimately what may change the unflattering views of the Finnish culture, people and styles of communication from the negative column to the positive. Third sector is also where important peer support could be organised. Trux (2002) has remarked that as well as wanting to make contacts with Finnish people, many skilled migrants feel the need to meet their compatriots and partake in activities in their own language. As one informant puts it: The coldness of Finnish people is starting to get to me. If I had not been able to talk about my impressions with other foreigners at our company, I would have probably gone crasy (ibid:205).

Paying more attention to social integration outside the workplace would complete the continuum of successful skilled migration policies from recruitment to arrival, and to integration that aims at committing the migrants to stay. In this aspect research into the social sphere of the lives of skilled migrants in Finland can be

\footnotetext{
15 There are already such services, but the field functions mainly on voluntary and hobby basis and attracts hardly any public funding. For an example, see Jolly Dragon, a Helsinki based activities organisation bringing together Finns and foreigners in a social setting (www.jollydragon.net).
} 
helpful in the global competition for skilled talent. Good social policy will also help to establish a better reputation for Finland as a viable option in the global field of choices.

\section{Conclusion}

Having long been a country of (labour) emigration, Finland has seen the tide turn towards immigration. This trend needs to be actively strengthened to counterbalance the effects of a rapidly aging population in order to maintain the current levels of welfare state and its support ration.

Research in the field has showed that skilled migrants see the Finnish levels of wages and taxes as major draw-backs. It is clear that adjustment of preferential taxing systems and possibilities for opting out of welfare state services should be implemented. Furthermore, the possibility for a type of Green Card scheme or points system for skills-based admission should also be explored in order to establish Finland as a serious contender for global talent.

However, research into the social sphere of skilled migrants' lives shows that social integration programmes are also desperately needed. Finland and its people are seen as distant, unfamiliar and cold, and the skilled migrants feel unattached from the society at large. These issues have been left out of discussion about policies concerning skilled migration. Skilled immigrants are viewed as temporary employees rather than permanent additions to the Finnish workforce and society. Therefore designing policies for social integration has not been considered necessary.
This attitude has been proven wrong before; integration policies only became an issue after humanitarian migrants ended up staying against predictions. In relation to skilled migrants, integration policies should be an issue in order to persuade them to stay, against predictions.

Kaisu Koskela (MSc)

$\mathrm{PhD}$ candidate

Department of Sociology,

University of Helsinki

kaisu.koskela@helsinki.fi

\section{Bibliography}

Appleyard, Reginald (1989) The impact of international migration on developing countries, Paris, OECD, 459 p.

Auriol, Laudeline; Sexton, Jerry (2002) Human resources in science and technology: Measurement issues and international mobility, International mobility of highly skilled, OECD proceedings, Paris, pp. 13-38.

Carroll, Hanna [et al (2009) Työmarkkinoiden kansainvälistymis- palvelut: Ulkomaalaisen osaamisen kanava Suomen elinkeinoelämään. Kebittämisen baasteet ja mabdollisundet pääkaupunkiseudulla, Helsinki, Helsingin kaupungin Tietokeskus, $170 \mathrm{p}$.

Dumont, Jean-Christophe ; Lemaitre, Georges (2005) Counting Immigrants and Expatriates : A New Perspective, OECD (Social, Employment and Migration Working papers No. 25) disponible sur internet

$<$ http://www.oecd.org/dataoecd/27/5/338 68740.pdf $>$ 
ETNO (2008) Järjestöjen rooli byvien etnisten subteiden edistämisessä sekä kotouttamisen kehittämisessä, disponible sur internet : $<$ http://www.intermin.fi/intermin/images.n sf/files/A5F297DFDBEB1B39C225750B00 447FE2/\$file/Liite6 jarjestojen kotouttami sen ja etnisen yhdenvertaisuuden politiikk a tyoryhman raportti.pdf $>$

Florida, Richard (2002) The rise of the creative class: And how it's transforming work, leisure, communityand everyday life, New York, Basic Books, 404 p.

Florida, Richard; Tinagli, Irene (2004) Europe in the Creative Age, London, Demos, $48 \mathrm{p}$.

Forsander, Annika (2002) Glocalazing capital and labor - old structures, new challenges, in Forsander, Annika (ed.) Immigration and Economy in the Globalization Process: The Case of Finland, Helsinki, Sitra, pp. 81-118, (Reports series, $\mathrm{n}^{\circ} 20$ ).

Forsander, Annika (2003) Insiders or outsiders within? Immigrants in the Finnish labour market, in Söderling, Ismo (ed.) Yearbook of population research in Finland, Helsinki, The population research institute, pp. 55-72.

Forsander, Annika [et al] (2004) Sykettä ja suvaitsevuntta: Globaalin osaamisen kansalliset rajat, Helsinki, Edita, 244 p.

Forsander, Annika [et al (2008) Economy, Ethnicity and International Migration. The Comparison of Finland, Hungary and Russia, in Söderling, Ismo (ed.) Yearbook of population research in Finland, Helsinki, The population research institute, pp. 85-114.

Forsander, Annika; Raunio, Mika (2005) Globalisoituvat työmarkkinat asiantuntijamaahanmuuttajat Suomessa, in Pitkänen, Pirkko (ed.) Kulttuurien välinen työ, Helsinki, Edita, 158 p.

Forsander, Annika ; Trux, Marja-Liisa (2002) Conclusion: Toward new Immigration Strategies?, in Forsander, Annika (ed.) Immigration and Economy in the Globalization Process: The Case of Finland, Helsinki, Sitra, pp.226-234 (Reports series, $\mathrm{n}^{\circ} 20$ ).
Global Commission on International Migration (2005), Migration in an interconnected world: New directions for action, disponible sur internet :

$<$ http://www.gcim.org/attachements/gcimcomplete-report-2005.pdf $>$

Hautala, Johanna (2006) Oulun yliopiston ulkomaalaiset osaajat, Pro Gradu, University of Oulu, 109 p.

Jasinskaja-Lahti, Inga [et al] (2002) Rasismi ja syrjintä Suomessa: Maabanmunttajien kokemuksia, Helsinki, Gaudeamus, 214 p.

Statistics Finland (2008) The Population of Finland in 2008, disponoble sur internet: $<$ http://www.stat.fi/til/vaerak/2008/vaera k 2008 2009-03-27 tie 001 en.html>

Kananen, Kari (2006) Ulkomailta rekrytoidaan jo! Selvitys yritysten palvelutarpeista ulkomailta palkattavien työntekijöiden rekrytoinneissa, disponible sur internet: $<$ www.vantaanleija.fi/downloadelement.php ?id=2465\&f=Ulkomailta rekrytoidaan.pdf $>$ Kepsu, Kaisa; Vaattovaara, Mari (2008) Creative knowledge in the Helsinki Metropolitan area: Understanding the attractiveness of the metropolitan region for creative knowledge workers, Amsterdam, Amsterdam institute for Metropolitan and International Development Studies, 79 p. (ACRE report, $\left.\mathrm{n}^{\circ} 5.5\right)$.

Kepsu, Kaisa[et al](2009) Helsinki: An attractive metropolitan region for creative knowledge workers? The view of transnational migrants, Amsterdam, Amsterdam institute for Metropolitan and International Development Studies, (ACRE report WP7.5), disponible sur internet: $<$ http://acre.socsci.uva.nl/results/documen ts/7.5helsinki FINAL.pdf $>$

Raunio, Mika (2001) Osaajat valintojen kentällä. Helsingin, Tampereen, Turun, Jyväskylän, Porin ja Seinäjoen seutujen vetovoimaisuus virtaavassa maailmassa, Tampere, Alueellisen kehittämisen tutkimusyksikkö, 159 p. (SENTE- publication 11).

Raunio, Mika (2002a) Image of Finland Divided Among Foreign ICT Professionals, Economic Trends 2, pp. 21-28. 
Raunio, Mika (2002b) Suomi globaalitalouden osaajien valintojen kentällä. Ulkomaalaisten buippuosaajien mielikuvat ja todellisundet suomalaisessa työ- ja kaupunkiympäristössä Tampere, Alueellisen kehittämisen tutkimusyksikkö, 198 p. (SENTEpublication 15).

Raunio, Mika (2003) Should I Stay or Should I Go?, The images and realities of foreign top professionals in Finnish working and urban environment: English Summary, Sente-working papers 6, disponible sur internet: $<$ www.sjoki.uta.fi/sente/linkkikirjasto $>$

Raunio, Mika (2005) Aivovuodosta aivokiertoon. Huippuosaajat talouden voimavarana, Helsinki, EVA-publications, 88 p.

Raunio, Mika; Sotarauta, Markku (2005) Highly Skilled Labor Force in the Global Field of Choices: Case Finland, disponible sur internet: $<$ http://www.uta.fi/ atmaso/verkkokirjast o/Raunio $\% 20 \& \% 20$ Sotarauta Highly $\% 20 \mathrm{~S}$ killed $\% 20$ Finland.pdf $>$

Silvain, Sagne [et al](2005) Active Civic Participation of Immigrants in Finland, Oldenburg, POLITIS European research project, (Country Report) disponible sur internet : <www.uni-oldenburg.de/politiseurope/download/Finland.pdf $>$

Sippola, Aulikki [et al](2006) Kulttuurisesti monimuotoistuvien työybteisöjen kehittäminen, disponible sur internet: $<$ www.mol.fi $/ \mathrm{mol} / \mathrm{fi} / 99 \mathrm{pdf} / \mathrm{fi} / 06$ tyomin isterio/06 julkaisut/06 tutkimus/tpt304.pdf
Trux, Marja-Liisa (2000) Monimuotoinen työyhteisö, in Trux, Marja-Liisa (ed.) Aukeavat ovet -kulttuurien moninaisuus Suomen elinkeinoelämässä, Helsinki, WSOY, pp. 261316 (Sitra 238).

Trux, Marja-Liisa (2002) Diversity under the Northern Star, in Forsander, Annika (ed.) Immigration and Economy in the Globalization Process: The Case of Finland, Helsinki, Sitra, pp.175-225 (Reports series, $\mathrm{n}^{\circ} 20$ ).

UN Department of Economic and Social Affairs' Population Division (2007) World Population Indicators 2007, disponible sur internet :

$<\underline{\text { http://www.un.org/esa/population/publi }}$ cations/wpp2007/WPP2007\%20web/Coun tries/WPP2007\%20Frame.htm>

Wallenius, Tapio (2001) Vieraassa vara parempi? Suomen maahanmuuttopolitiikan haasteet, Helsinki, Taloustieto Oy, Eva, 48 p.

Yijälä, Anu (2008) Factors Ensuring Integration Among International High Skilled Professionals in Finland (InterProF) (project summary), disponible sur internet: $<$ http://www.hel.fi/wps/wcm/connect/99 6e08804acff1 feae46ae2f97c8a9f5/InterProF summary 2008.pdf?MOD=AJPERES> 